\title{
Management of the innovation and investment cycles at the energy enterprises
}

\author{
Elena Zubeeva ${ }^{1, *}$ Marina Mirgorodskaya ${ }^{1}$, Yuri Geraskin ${ }^{2}$, Andrei Chugunov ${ }^{3}$, Oksana \\ Belyantseva $^{3}$ \\ ${ }^{1}$ Moscow state University of technology and management. K.G. Razumovsky, Zemlyanoy Val street, \\ 73, Moscow, 109004, Russia \\ ${ }^{2}$ Moscow State University of Civil Engineering, Yaroslavskoye shosse, 26, Moscow, 129337, Russia \\ ${ }^{3}$ Voronezh State Technical University, Moscow Avenue, 14, Voronezh, 394026, Russia
}

\begin{abstract}
The purpose of this paper is the substantiation and confirmation of the main provisions to the formation of instruments for the balanced development of the innovation and investment cycles at the energy enterprises. The basic principles of the balanced development of the innovation and investment cycles in the economic systems are determined, key problems of management of the balanced development of the innovation and investment cycles are identified and potential solutions are determined. Internal and external factors are analyzed, efficiency criteria for management are formed, and a mechanism for managing the balanced development of the innovation and investment cycle at the energy enterprises is developed.
\end{abstract}

\section{Introduction}

The key components of the intensification of the development of the domestic economy are innovation and investment activities. The production and sale of innovative products that can provide accelerated rates of development of both new and traditional sectors of the economy requires a radical renovation of fixed capital assets.

Under the current conditions, the energy enterprises are characterized by limited sales market, both in the domestic and foreign markets, due to the general technological backwardness of the industry. On the one hand, this leads to the serious problems for accumulating the investment resources for the implementation of production and economic activities, including the implementation of innovation activities. On the other hand, the lack of funds for innovation activities leads to an open cycle of innovative development of the energy enterprises, including scientific development, experimental development, pilot production, batch production and sale of products to consumers with the return of funds and subsequent reinvestment in the innovation activities. Thus, improving the management of the balanced development of innovation and investment cycles at the energy enterprises is an urgent scientific task of great economic importance [1].

\footnotetext{
* Corresponding author: helen400@yandex.ru
} 


\section{Materials and methods}

The basis for all considered schemes for the balanced development of the innovation and investment cycles is the interdependence of areas for the industrial (at the macro-level) and functional (at the micro-level) development of economic systems. At the same time, the level of proportionality of the development of certain industrial (or functional) areas has a great influence on the intensity and efficiency of the development of economic systems as a whole [2].

In its content, any of the schemes for the balanced development of the innovation and investment cycles in the economic systems are:

- the management system containing feedback and aimed at the continuous development;

- the mechanism for implementing the strategy and its correction;

- the tool of transference of the strategy into the plane of specific goals, indicators and tasks;

- the tool for monitoring the implementation of the strategy and forecasting indicators of future periods.

At the same time, none of the models presented in Table 1 does fully represent the specific nature of the balanced development of the innovation and investment cycles in the economic systems.

As the basic principles of the balanced development of the innovation and investment cycles in the economic systems the following are considered: systematicity, sustainability and continuity of development, focus, differentiation and temporal certainty.

The principle of sustainability and continuity of development means the absence of discontinuities in the innovation and investment cycles of the economic systems while ensuring the stable growth of the results of financial and economic activities.

The principle of focused balanced development means the orientation of the innovation and investment cycles on the achievement of specific goals of the economic system, taking into account the existing potential capacity, conditions and limitations to achieve them [3].

Table 1. Basic approaches to the description of schemes of balanced development of the economic systems.

\begin{tabular}{|l|l|l|l|}
\hline № & Name of the model & The essence of the model & Instruments used \\
\hline 1 & $\begin{array}{l}\text { Model of inter- } \\
\text { industry balance } \\
\text { "input - output" by } \\
\text { Leontev V.V. }\end{array}$ & $\begin{array}{l}\text { Determination on the basis of the } \\
\text { method of economic analysis and } \\
\text { planning of the proportions of the } \\
\text { process of expanded reproduction, } \\
\text { ensuring the balance of inter- } \\
\text { industry production and distribution } \\
\text { of social product }\end{array}$ & $\begin{array}{l}\text { The method of analysis of } \\
\text { inter-industry relations on the } \\
\text { basis of a chess type tables } \\
\text { with the use of the tools of } \\
\text { linear algebra }\end{array}$ \\
\hline 2 & $\begin{array}{l}\text { Dynamic model of } \\
\text { inter-industry } \\
\text { balance by Veduta } \\
\text { N.I. }\end{array}$ & $\begin{array}{l}\text { Systemic harmonization of income } \\
\text { and outcome balances of } \\
\text { manufacturers and final consumers } \\
-\quad \text { nation state, enterprises, } \\
\text { households (intrastate balance), } \\
\text { exporters and importers (external } \\
\text { economic balance) }\end{array}$ & $\begin{array}{l}\text { The method of economic } \\
\text { cybernetics }\end{array}$ \\
\hline 3 & $\begin{array}{l}\text { Balanced Scorecard } \\
\text { (BSC) by D. Norton } \\
\text { and R. Kaplan }\end{array}$ & $\begin{array}{l}\text { Balanced scorecard is a concept of } \\
\text { transference and decomposition of } \\
\text { strategic goals into the tasks of } \\
\text { planning of operational activities } \\
\text { and monitoring their achievements } \\
\text { in areas of finance, customers, }\end{array}$ & $\begin{array}{l}\text { Key Performance Indicator } \\
\text { (KPI) which measure the } \\
\text { attainability of goals, as well } \\
\text { as } \\
\text { characteristics of business } \\
\text { processes in the areas of: }\end{array}$ \\
\hline
\end{tabular}




\begin{tabular}{|l|l|l|l|}
\hline & & $\begin{array}{l}\text { internal business processes, } \\
\text { opportunities for training and } \\
\text { growth. }\end{array}$ & $\begin{array}{l}\text { finance, customers, internal } \\
\text { business processes, } \\
\text { opportunities for training and } \\
\text { growth. }\end{array}$ \\
\hline 4 & $\begin{array}{l}\text { The concept of } \\
\text { tactical and strategic } \\
\text { balanced economic } \\
\text { development of the } \\
\text { industrial } \\
\text { corporation } \\
\text { Selskov A.V. by }\end{array}$ & $\begin{array}{l}\text { It based on the principles of } \\
\text { sustainability and continuity of the } \\
\text { processes of interaction between } \\
\text { the innovation, investment } \\
\text { (financial) and production cycles (I- } \\
\text { F-P) of industrial corporation }\end{array}$ & $\begin{array}{l}\text { Strategy maps of Balanced } \\
\text { Scorecard (BSC) }\end{array}$ \\
\hline
\end{tabular}

The principle of differentiation of balanced development means ensuring, within the innovation and investment cycles, the expected by customer level of consumer values of the target market segments due to innovative development of products, technologies, development of new markets, etc. with the use of innovations of varying degrees of radicality.

The principle of temporal certainty of balanced development means that there are horizons for planning the resources of the innovation and investment cycles, on which their balance will be ensured, and the results of the implementation of these cycles.

Taking into account the identified basic principles, the trends in the development of tools and technologies for the balanced development of the innovation and investment cycles in the economic systems were studied [4].

Developed in the process of study, the algorithm for solving the problems of managing the balanced development of the innovation and investment cycles at the energy enterprises contains:

- analytical block for determining the opportunities and prospects for improving the efficiency of a balanced development of the innovation and investment cycles, aimed at the formation of the efficiency criteria for managing the balanced development of the innovation and investment cycles;

- synthetic block aimed at developing the mechanism for managing the balanced development of the innovation and investment cycles;

- practical block associated with the implementation of recommendations for the application of tools for the balanced development of the innovation and investment cycles.

The analysis of the opportunities and prospects for improving the efficiency of the balanced development of the innovation and investment cycles at the energy enterprises revealed that they are mainly caused by the negative influence of external and internal factors, which predetermines the necessity to improve the management system.

\section{Results}

This improvement should be based on the efficiency criteria for managing the balanced development of the innovation and investment cycles at the energy enterprises.

When developing the efficiency criteria for managing the balanced development of the innovation and investment cycles, the following should be taken into account: the required rate of development of enterprises; level of differences in the results of financial and economic activity, determined by technological gaps in the activities of the enterprise; indicators of the financial position of the enterprise and its financial solvency [5].

The proposed efficiency criterion for managing the balanced development $\left(\mathrm{K}_{\mathrm{av}}\right)$ of the innovation and investment cycles at the enterprises is: 


$$
K_{a v}=\prod_{j=1}^{N=7} K_{j}
$$

where $K_{j}$ - relative criterion of efficiency of the balanced development of the innovation and investment cycles in the $\mathrm{j}$-th component;

$K_{1}$ - relative rate of development of the enterprise against the backdrop of the development rates of the serviced branches of economic management, determined from the equation:

$$
K_{1}=\frac{T_{\text {ent.inv.. }}}{\left(T_{d e}+0,25 \cdot T_{h t}\right)},
$$

where $T_{\text {ent.inv. }}-$ average rate of development of the enterprise during the period of invention (9 years),

$\mathrm{T}_{\mathrm{de}}$ - average rate of development of the national economy during the period of invention,

$\mathrm{T}_{\mathrm{ht}}$ - average rate of development of the high-tech industries of the national economy during the period of invention;

$K_{2}$ - relative rate of development of the enterprise against the backdrop of the rate of development of the leader-enterprise in the industry, determined from the equation:

$$
K_{2}=\frac{T_{\text {ent.innov. }}}{T_{\text {l.innov. }}}
$$

where $\mathrm{T}_{\text {ent.innov. }}$ - average rate of development of the enterprise during the period of innovation (4 years),

$\mathrm{T}_{\text {l.innov. }}$ - average rate of development of the leader-enterprise during the period of innovation; $\quad K_{3}$ - relative profitability of the enterprise at the industry average level, determined from equation:

$$
K_{3}=\frac{R_{\text {ent.mod. }}}{R_{\text {ind. } \bmod .}} \cdot \frac{T_{\text {R.ent }}}{T_{\text {R.ind }}},
$$

where $\mathrm{R}_{\text {ent.mod. }}$ - average profitability of the enterprise during the period of modernization (2 years),

$\mathrm{R}_{\text {ind.mod. }}$ - average profitability of the industry during the period of modernization,

$T_{R . e n t}$ - average rate of growth of profitability of the enterprise during the period of modernization,

$\mathrm{T}_{\mathrm{R} . \text { ind }}$ - average rate of growth of profitability of the industry during the period of modernization;

$\mathrm{K}_{4}$ - coefficient of determination, characterizing the degree of deviation of the performance indicators of the economic activity of the enterprise from the given trend, determined from the equation:

$$
K_{4}=H_{r} \cdot H_{i} \cdot H_{p r}
$$

$\mathrm{H}_{\mathrm{r}}, \mathrm{H}_{\mathrm{i}}, \mathrm{H}_{\mathrm{pr}}$ - coefficients of determination, characterizing the degree of deviation of the indicators from the given trend by revenue, income and profit during the investment cycle (4 years).

$\mathrm{K}_{5}$ - relative indicator of the liquidity of the enterprise, determined from the equation: 


$$
K_{5}=\frac{L_{e n t}}{L_{r e q}},
$$

$\mathrm{L}_{\text {ent }}-$ average level of liquidity of the enterprise during the period of investment cycle;

$\mathrm{L}_{\text {req }}$ - required (normative) level of liquidity of the enterprise during the period of investment cycle;

$\mathrm{K}_{6}$ - relative indicator of the turnover of the enterprise's funds, determined from the equation:

$$
K_{6}=\frac{O_{e n t}}{O_{r e q}},
$$

$\mathrm{O}_{\text {ent }}-$ average level of turnover of enterprise's funds during the period of modernization cycle;

$\mathrm{O}_{\text {req }}$ - required (normative) level of turnover of enterprise's funds during the period of modernization cycle;

$\mathrm{K}_{7}$ - relative indicator of financial sustainability of the enterprise, determined from the equation:

$$
K_{7}=\frac{F_{e n t}}{F_{r e q}},
$$

$\mathrm{F}_{\text {ent }}$ - level of financial sustainability of the enterprise during the period of simulation cycle (1 year);

$\mathrm{F}_{\mathrm{req}}$ - required level of financial sustainability of the enterprise during the period of simulation cycle.

Thus, the proposed efficiency criterion for managing the balanced development of the innovation and investment cycles at the enterprises takes into account the indicators of innovation development within the cycles of inventions, innovations and modernizations and investment support for innovative development within the cycles of innovations, modernizations and inventions.

The mechanism is proposed on the basis of the revealed features (Figure 1). It allows using rational models of management of the balanced development of the innovation and investment cycles to manage the parameters of the balanced development. Also, using the developed criteria, it allows assessing the efficiency of management of the balanced development within the cycles of inventions, innovations, modernizations and imitations, and developing the necessary corrective actions [6]. 


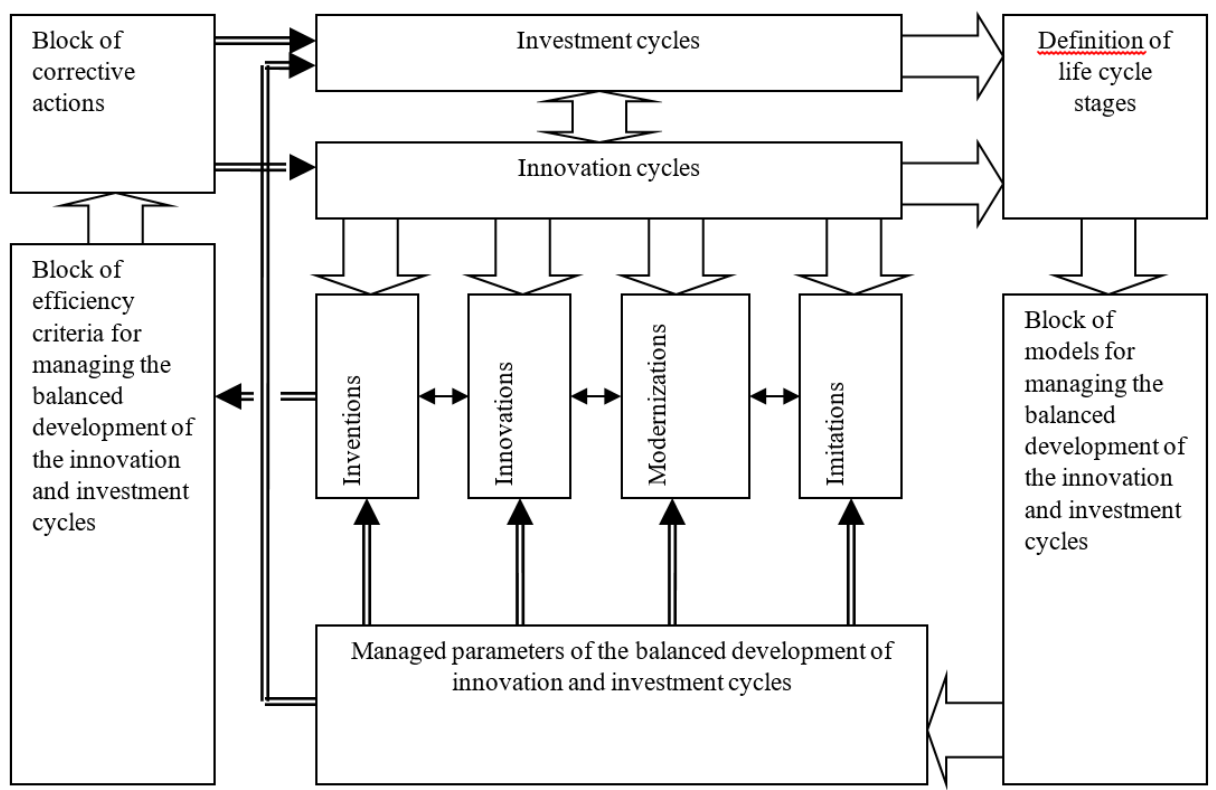

Fig. 1. Scheme of the mechanism for managing the balanced development of the innovation and investment cycles in the economic systems.

\section{Discussion}

Under current conditions, the main trends in the development of tools for the balanced development of innovation and investment cycles in the economic systems are associated with the use of tools for intensification of innovation and investment activities and technologies for the integrated implementation of innovations with varying degrees of radicality. Analysis of environmental factors indicates that the most positive effect is produced by the following indicators: electricity consumption, entrepreneurial confidence, total industrial output, and volumes of high-tech industrial output [7, 8]. Analysis of internal factors that determine the balance of development of the innovation and investment cycles at the enterprises has shown that the greatest positive influence is made by the indicators of implementation of product innovations in the innovation activity of the enterprises.

\section{Conclusion}

The proposed mechanism for managing the balanced development of the innovation and investment cycles at the energy enterprises allows using rational models of management of the balanced development of the innovation and investment cycles to manage the parameters of development. Also, using the developed criteria, it allows assessing the efficiency of management of the balanced development within the cycles of inventions, innovations, modernizations and imitations, and developing the necessary corrective actions.

\section{References}

1. A.D. Ishkov, T.N. Magera. Procedia Engineering 117, 148-153 (2015) 
2. Y.V. Larionova, S.A. Pavlova, Life Science Journal 12, 650 (2014)

3. Y. Panibratov, A. Larionov, Applied Mechanics and Materials 8, 725-726 (2015)

4. I.V. Ilin, A.I. Levina, O.Yu. Iliashenko, MATEC Web of Conf. 86, 05028 (2016) doi: 10.1051/matecconf/20168605028

5. O. Kalinina, O. Valebnikova, Advances in Intelligent Systems and Computing 692, 1315-1322 (2018) doi: 10.1007/978-3-319-70987-1_139

6. R.S. Golov, V.V. Shilov, S.A. Silantiev, ASEE International Forum, Columbus, 20766 (2017)

7. A. Jones, G. Fallon, R. Golov, European Business Review 12(4), 187-197, doi. 10.1108/09555340010336871

8. E. Kiseleva, M. Nekrasova, M. Mayorova, M. Rudenko, V. Kankhva, International Review of Management and Marketing 6, 95 (2016) 